\title{
Cisinta
}

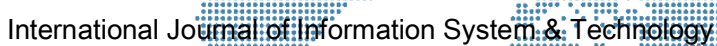

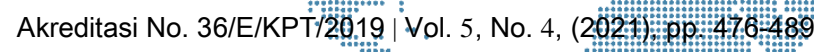

\section{Evaluation and Development of Web-Based Information Systems of Unit Pelaksana Teknis Mengwi District Based on Usabiliny ": Method and User Experience}

\author{
I Made Suryana Dwipa ${ }^{1}$, I Made Candiasa ${ }^{2}$, Luh Joni Erawati Dewi ${ }^{3}$ \\ ${ }^{1,2,3}$ Universitas Pendidikan Ganesha \\ ${ }^{1}$ suryanadwipa83@gmail.com, ${ }^{2}$ candiasa@undiksha.ac.id, \\ joni.erawati@undiksha.ac.id
}

\begin{abstract}
Unit Pelaksana Teknis (UPT) of Mengwi District is one of the regional agencies of Badung Regency. UPT Mengwi has an important task in terms of educational services in the Mengwi District. There were several problems found by users namely problems related to the interface and some functional system which did not run optimally. Therefore, continuous evaluation and development were needed. The evaluation of SIUPT Mengwi was carried out using the evaluation techniques of Performance Measurement, Retrospective Think Aloud, and User Experience Questionnaires. The results in the initial evaluation phase with the Performance Measurement technique showed that it was still not effective and efficient. The analysis of user satisfaction on the attractiveness aspect was 1.45, clarity aspect was 1.05, efficiency aspect was 1.21, and accuracy aspect was 1.45. It discovers that the satisfaction Level of the SIUPT Mengwi has not reached the set standard so that development efforts were needed. The results of the evaluation after the development phase showed that SIUPT has been effective and efficient with a failure rate of $0 \%$ and there was no significant difference in the time to complete the task. All aspects of user satisfaction gained a very good category with an average score for the attractiveness aspect which was 2.39, the clarity aspect was 2.29, the efficiency aspect was 2.50, the accuracy aspect was 2.41, the stimulation aspect was 2.43 and the novelty aspect was 2.40. For future evaluation and development, some improvements can be made to the Graphic User Interface (GUI) on the system to improve the research which will be carried out.
\end{abstract}

Keywords: evaluation, development, usability, user experience.

\section{Introduction}

Information systems are needed for educational services, one of them is used at UPT Mengwi. Unit Pelaksana Teknis (UPT) of Mengwi District is one of the regional agencies of Badung Regency. UPT Mengwi has an important task in terms of educational services in Mengwi District. The UPT of Mengwi District has an important tasks in education administration, such as personnel management and routine budget administration management for elementary and junior high schools in Mengwi District. Personnel Management includes in terms of compiling and monitoring proposals for promotion, penetapan angka kredit (PAK), tunjangan profesi guru (TPG), kenaikan gaji berkala (KGB), pensions and termination of employees in accordance with applicable procedures and provisions. Routine budget administration management includes proposing incentives or other benefits to the finance department.

There were some problems found by users when using the SIUPT system related to the interface, namely, 1) the system display is still not attractive, 2) there are too many menus on the system that should be grouped, 3) the button layout needs to be taken into account such as the action button on the right side of the page, when there is long data to the 


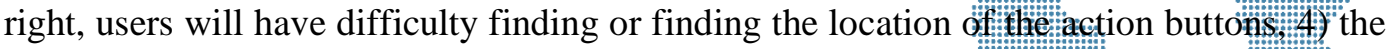
location of the data search feature at the bottom of the page and grammar. In addition, several problems related to system funcetionality werêt found, namely, 1) the data search feature is still not functioning optimally, 2) in data filter feature, the function is still unclear. From the problems found, it is necessary to evaluate and develop on an ongoing basis from SIUPT Mengwi so that it can be used by users more effectively, efficiently, and provide a level of satisfaction to the scope of its users.

In this study, the usability testing method was used to validate all the functional requirements of SIUPT Mengwi according to user needs [5]. Usability testing has several evaluation techniques, one of them is Performance Measurement [4]. Another technique that can also be combined with the Performance Measurement technique is the Retrospective Think Aloud (RTA) technique [10]. Retrospective Think Aloud (RTA) is a technique that allows respondents to tell their activities when they have completed the given task [3]. Both techniques were easier to use and could measure important aspects of usability, namely effectiveness, efficiency, and user satisfaction in using the Mengwi SIUPT system.

In this study, in evaluating to measure the level of satisfaction in using the system using the User Experience Questionnaire (UEQ). UEQ is able to provide an overview from usability aspects to user experience [7]. The User Experience Questionnaire (UEQ) covers six aspects of user experience with a total of 26 statements [6]. Each of these aspects in Indonesian is accuracy, clarity, attractiveness, efficiency, novelty and stimulation. The development phase applies the incremental model. The incremental model can minimize the risk of defects during the development process because each released system is evaluated in stages [8]. The development of SIUPT which was carried out in stages based on the results of user evaluations was the basis for using the incremental model in this study.

Based on the explanation above, in this study an initial evaluation of the previous system was carried out. SIUPT evaluation was done by using Performance Measurement, Retrospective Think Aloud and User Experience Questionnaire evaluation techniques. The results of the recommendations for improvement were then used as initial analysis data in the subsequent development phase of the Mengwi SIUPT using the incremental development model. The development of SIUPT Mengwi continues to be carried out until it meets the level of user satisfaction. The final result of this research is expected to produce SIUPT Mengwi which has been developed in terms of interface, functional, and user experience and is easy to understand.

\section{Research Methodology}

\subsection{Research Stages}

The initial stage of this research begins with identifying the problems in SIUPT Mengwi, namely the system interface and functional systems that have not been running optimally. After a discussion with the Head of the UPT Mengwi, the researchers concluded that an evaluation and development of the Mengwi SIUPT is needed to further improve the quality of services for elementary and junior high schools in Mengwi District. The next stage was conducting a literature study related to the techniques for evaluating and developing the Mengwi SIUPT. Literature studies used are references from research journals, theses, articles, and books. The stages of the overall research carried out are shown in Figure 1. 


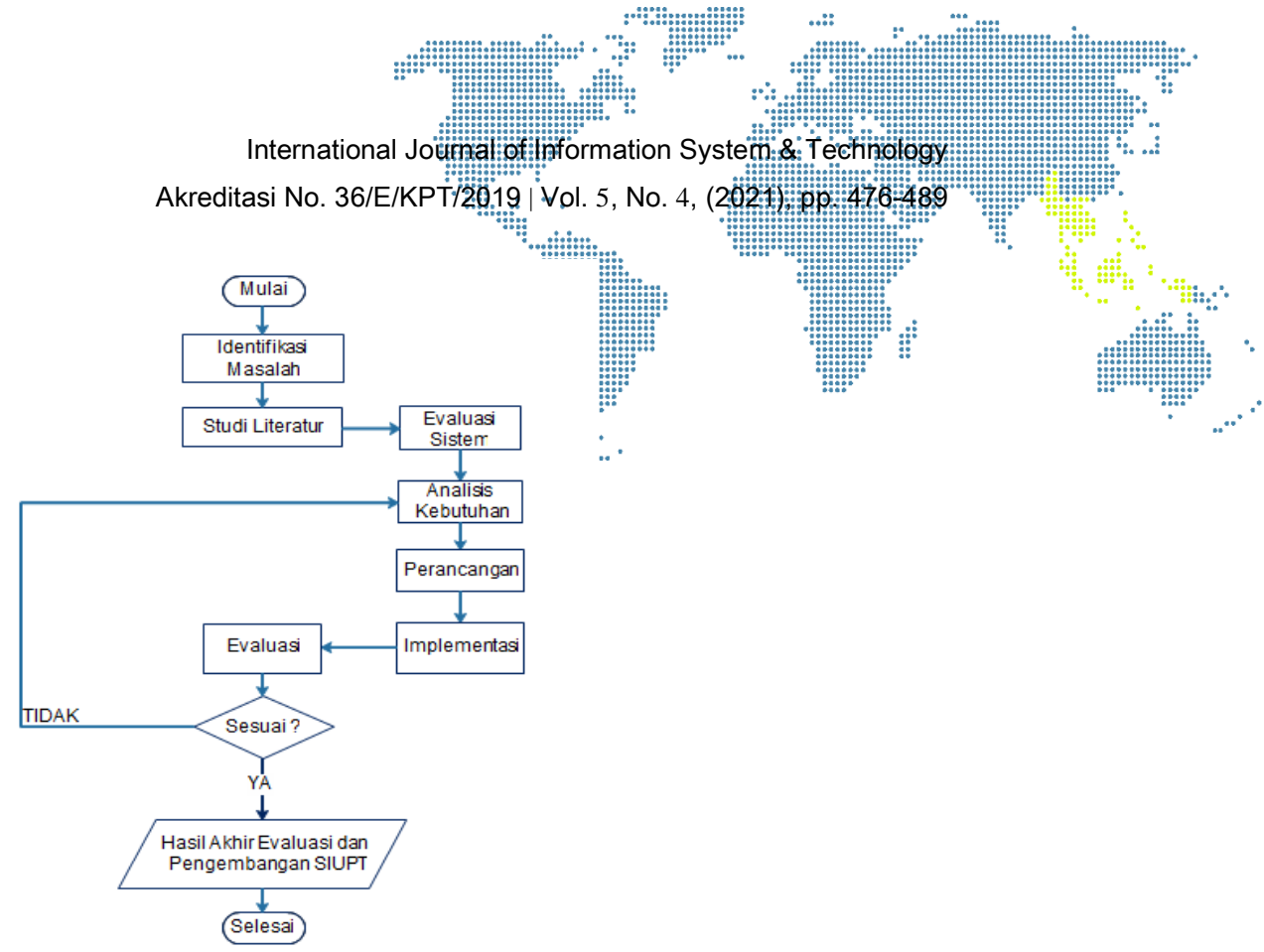

Figure 1. Research Stages

\subsection{Research Respondents}

In this study, the determination of respondents using simple random sampling technique [11]. This study used 20 respondents who were SIUPT Mengwi users, namely UPT employees who served in the field of personnel administration, as well as elementary and junior high school employees in Mengwi District who served in the personnel field.

\subsection{Performance Measurement}

The Performance Measurement method is used to generate quantitative data regarding the performance of respondents when they complete a given task [11]. The Performance Measurement technique is carried out by recording the screen into a video using Bandicam software when the respondent performs a test and plays back the resulting video data, then the respondent's processing time is calculated from the video. Quantitative data generated from the Performance Measurement technique was the user's success in carrying out each task given by looking at the number of errors made by the respondent. Researchers can also assess the efficiency of the Mengwi SIUPT through data analysis of the speed at which the tasks performed by each group of respondents. Mann Whitney U-Test is a non-parametric statistical test that is used to compare two independent groups or different participants in each group and is an alternative to the ttest in parametric statistics. Some things that can be done with the Mann Whitney U-test are as follows [2].

1. Rank each number. Ranking is a process of compiling a data set in which the actual value of the data varies,

2. Added grades that have been ranked under several conditions,

3. Test the total of a number of ranks,

4. Test whether two population means are the same or not.

\subsection{Retrospective Think Aloud}

Data collection with the RTA technique was carried out on respondents after the Performance Measurement data collection process was completed [11]. In collecting data using RTA, before starting to play back the video data obtained from data collection using the Performance Measurement technique, respondents were instructed to be able to tell as clearly as possible what the respondent thought when the respondent carried out the stages to complete the requested task. Then in the process of collecting data, it is done by recording everything that the respondent expresses for further processing of each respondent's recording. 


\subsection{User Experience Questionnaire}

The technique of collecting data on the UEQ is done by filling out a questioninaciene [9].

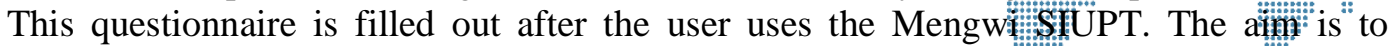
quantitatively measure the value of user experience after using the system. The value of the Mengwi SIUPT user experience is measured in terms" of clarity, accuracy, attractiveness, efficiency, novelty and stimulation with using a semantic differential measurement scale which is almost the same as the Likert scale used to measure a person's opinions, attitudes and perceptions. The final result of the UEQ is depicted in a benchmark chart that shows the quality of the product into five categories [1].

\section{Results and Discussion}

\subsection{Results and Discussion Evaluation Phase}

This section describes the results of the evaluation conducted on the SIUPT Mengwi. Each stage carried out in this phase is described as follows.

\subsubsection{Evaluation Results - Performance Measurement}

The data obtained from the usability testing process with the Performance Measurement technique obtained data on task failures and data on task completion time for 20 respondents on the Administrator page (UPT Employee), school employees hich can be seen as follows.

\section{a) Results and Analysis of Effectiveness on Administrator Page.}

The first attempt at using the Administrator page got an average error percentage of $6.18 \%$. In the second experiment there was a decrease in the average percentage error of $4.41 \%$. There were 3 factors that cause failure, namely 1) The placement of the save button was still not in a right position, 2) the location of the search button was not right and did not function optimally, 3) the use of language was inconsistent.

\section{b) Results and Analysis of Effectiveness on School Employee Pages.}

The first experiment on using the school employee page got an average error percentage of 3.64\%. In the second experiment, the average error percentage decreased by $2.27 \%$. There were 3 factors that cause failure, namely 1 ) the position of the action button was less effective, 2) the location of the save button was less efficient, 3) the location of the search button was not right at the bottom of the page, and it was not functioning optimally.

From several factors causing failure, it is known that there are 3 factors, namely 1) the position of the action button was less effective, 2) the placement of the save button was less efficient, 3) the location of the search button was not right at the bottom of the page, and it has not functioned optimally.

a) Results and Analysis of Efficiency on Administrator Page.

Statistically, there were 8 tasks that can be stated to have no significant difference and 9 other tasks have a significant difference in time from the execution of each task on the Administrator page in test 1 and test 2 .

b) Results and Analysis of Efficiency on School Employee Page.

Statistically, there were 6 tasks that can be stated that have no significant difference and the other 5 tasks have a significant difference from the processing time for each task on school employee page in test 1 and test 2.

\subsubsection{Evaluation Results - Retrospective Think Aloud}

Data recapitulation of difficulties or problems when using SIUPT as well as suggestions and criticisms obtained from respondents for the use of SIUPT from admins (UPT employees) and school employees can be seen as follows.

\section{a) Evaluation Phase - Conclusion of RTA on Administrator Page}

The conclusion data from the recapitulation of data on difficulties or problems when using SIUPT Mengwi as well as suggestions and criticisms obtained from respondents for 
using SIUPT Mengwi for the Administrator page with RTA Table 1.

Table 1. Conclusion of RTA on Administrator fage

\begin{tabular}{|c|c|c|}
\hline No & Features/Aspects & Conclusion \\
\hline 1. & $\begin{array}{l}\text { Clarity of the } \\
\text { menu on the } \\
\text { system }\end{array}$ & $\begin{array}{l}\text { 1. Menus need to be grouped, to make it easier to } \\
\text { access }\end{array}$ \\
\hline 2. & Button on system & $\begin{array}{l}\text { 1. The save button also needs to be placed at the } \\
\text { bottom. } \\
\text { 2. Action buttons need to be placed on the left side of } \\
\text { the page } \\
\text { 3. Clarify button coloring } \\
\text { 4. The exit or logout button is moved to the top of the } \\
\text { page. }\end{array}$ \\
\hline 3. & Search feature & 1. Search button moved to the top of the page \\
\hline 4. & Filter features & $\begin{array}{l}\text { 1. The function of the data filter button is made clearer } \\
\text { and according to its function of displaying data. }\end{array}$ \\
\hline 5. & Use of grammar & 1. Use consistent Indonesian. \\
\hline
\end{tabular}

\section{b) Evaluation Phase - Conclusion of RTA on School Employee Page}

The conclusion data from the recapitulation of data on difficulties or problems when using SIUPT Mengwi as well as suggestions and criticisms obtained from respondents for using SIUPT Mengwi for the Administrator page with RTA evaluation can be seen in

Table 2.

Table 2. Conclusion of RTA on School Employee Page

\begin{tabular}{|c|c|c|}
\hline No & Features/Aspects & Conclusion \\
\hline 1. & $\begin{array}{l}\text { Clarity of the } \\
\text { menu on the } \\
\text { system }\end{array}$ & $\begin{array}{l}\text { 1. Menus need to be grouped, to make it easier to } \\
\text { access. }\end{array}$ \\
\hline 2. & Button on system & $\begin{array}{l}\text { 1. The save button also needs to be placed at the } \\
\text { bottom. } \\
\text { 2. Action buttons need to be placed on the left side } \\
\text { of the page } \\
3 \text {. The exit or logout button is moved to the top of } \\
\text { the page. }\end{array}$ \\
\hline 3. & $\begin{array}{l}\text { Features } \\
\text { system }\end{array}$ & $\begin{array}{l}\text { 1. The function of the data filter button is made } \\
\text { clearer and according to its function of displaying } \\
\text { data. } \\
\text { 2. Search button moved to the top of the page }\end{array}$ \\
\hline 4. & Use of grammar & 1. Use consistent Indonesian. \\
\hline
\end{tabular}

\subsubsection{Evaluation Results - User Experience Questionnaire}

Based on the data obtained the results of each aspect. Aspects of attractiveness, efficiency and accuracy obtained categories above the ideal average set. This category means that $25 \%$ of the results in the benchmark are better than the product being evaluated, $50 \%$ of the results are worse. Furthermore, in the aspect of clarity, the category was below the ideal average, which means that $50 \%$ of the results in the benchmark were better than the product being evaluated, $25 \%$ of the results were worse. While the stimulation and novelty aspects showed a very good category, which means that the product being evaluated was among the best $10 \%$ of results. 


\section{Cisinta}

International Jo:ürmal:of Information System: \& Téchinology Akreditasi No. 36/E/KPT/2019 | Vol. 5, No. 4, (202.21) pp. 476.489

The results of the user experience questionnaire showed that the SIUPT extaluation phase could provide attractiveness, efficiency and accuracy in geiting categories above the ideal average. The clarity aspect got a category below the ide average and the stimulation aspect, novelty got a very good category. The conclutisions obtained in the evaluation phase of the Mengwi SIUPT still need to be improved on several parts related to the attractiveness, efficiency, accuracy and clarity of the Mengwi SIUPT. Therefore, SIUPT Mengwi continued to the incremental phase, namely the development and reevaluation of the system that had been developed.

\subsection{Results and Discussion of the Development Phase}

This section describes the results and analysis of the SIUPT evaluation carried out in the evaluation phase of the existing system. Furthermore, system development is carried out on the results obtained from the previous SIUPT evaluation analysis. In the development phase, for each stage carried out is described as follows.

\subsubsection{Design Results}

The results of the analysis carried out indicate that there is a need that has been developed in the SIUPT system. The results of the needs analysis in this development phase are then modeled using Data Flow Diagrams, Entity Relationship Diagrams (ERD) and table structure planning for database management at SIUPT Mengwi.

a) Data Flow Diagrams - Context Diagrams

Users in this SIUPT are administrators (UPT employees), school employees and the head of the UPT. For more details on the process flow of the Mengwi SIUPT, Figure 2.

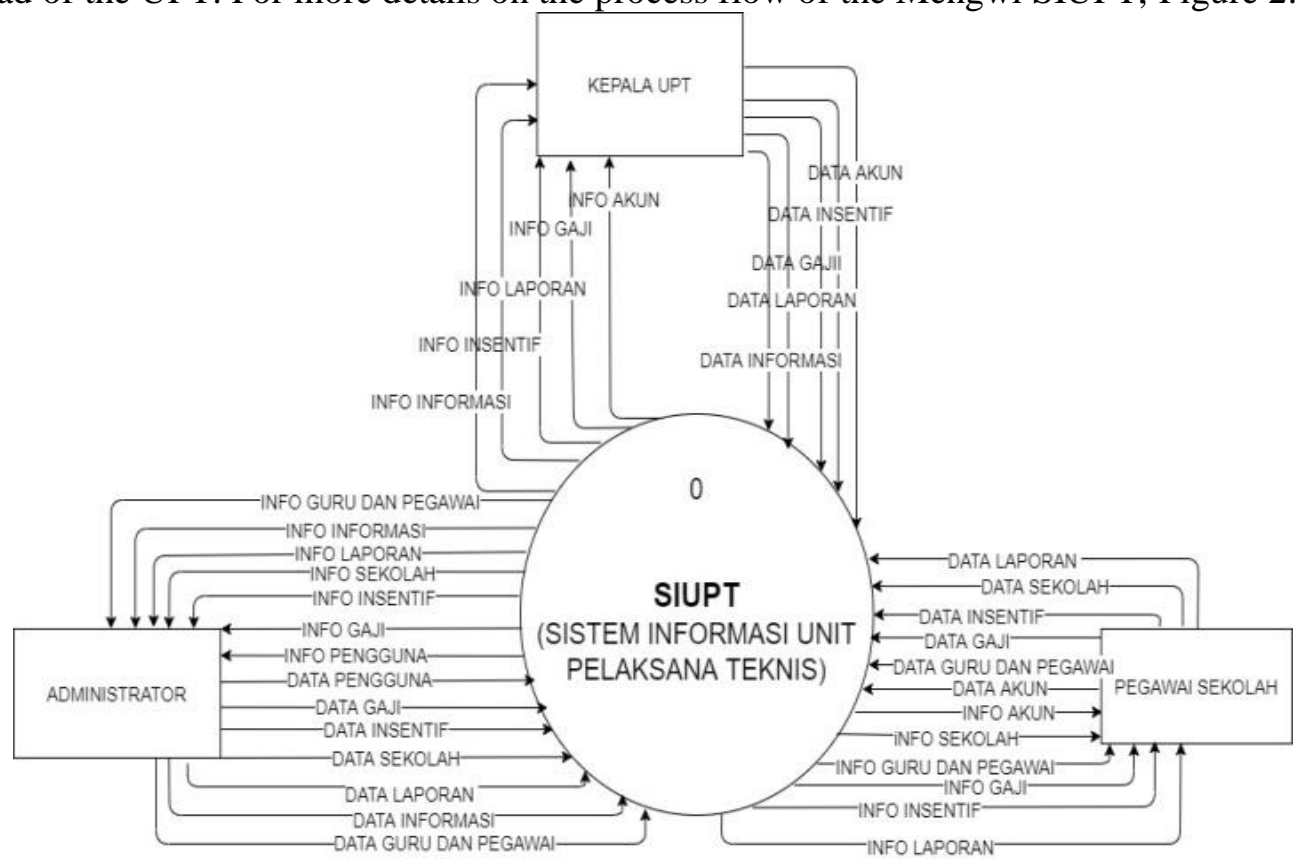

Figure 2. SIUPT Context Diagram

b) Data Flow Diagrams - Level 0

In this system, the data that is entered or the command given is then processed by the data processing or data manipulation process. In addition to processing data, the system can also store data and retrieve data information from storage. At DFD Level 0 SIUPT consists of seven processes, namely the login process, the process of managing teacher and employee data, the process of managing salary data, the process of managing incentive data, the process of managing school data, the process of managing monthly report data and the process of managing information and news. Each process is stored in the database of each process. 


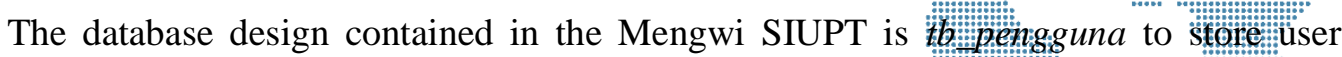
data, tb_tenaga to store personnel data, namely elementary: and junior higi: teachers and employees, tb_gaji to store employee salary data incentive data, $t b \_s e k o l a h$ to store elementary and junior high scthöol data, tb_sarana to store school facilities report data, $t b \_$prasarana to store school infrastructure report data, $t b \_s e k o l a h \_p e s e r t a d i d i k \_u s i a$ to store student age data, tb_sekolah_pesertadidik_agama to store student religious data, tb_sekolah_pesertadidik_mutasi to store student mutation data, tb_sekolah_pesertadidik_kps to store student KPS ownership data, tb_school_pesertadidik_transportasi to store student transportation data, tb_berita to store information and news data in SIUPT Mengwi. The following is a picture of DFD Level 0 SIUPT Mengwi, which can be seen in Figure 3 .

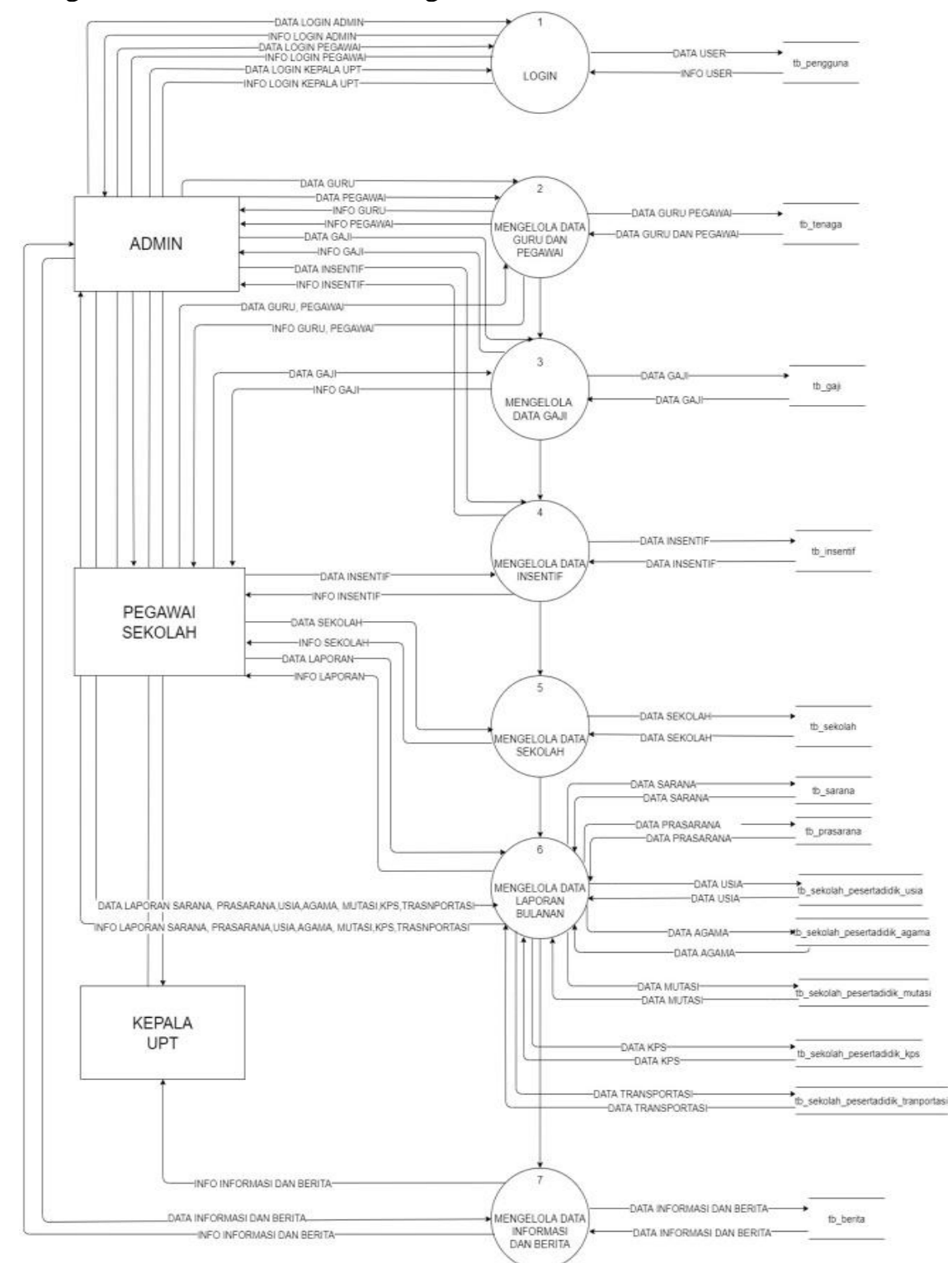

Figure 3. DFD Level 0

c) Entity Relationship Diagram

Entity Relationship Diagram(ERD) is a diagram used to design a database. ERD is used to show relationships or relationships between visible entities or objects and their attributes. Entity Relationship Diagram (ERD) is used as an initial stage in database 


\section{Cisinta}

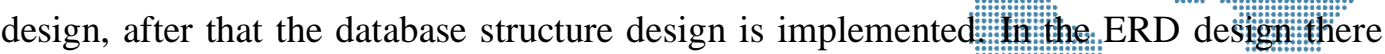
are relationships between entities which are described as follows

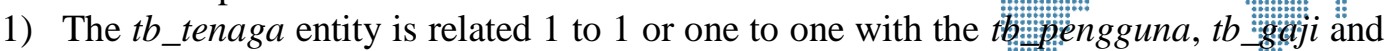
tb_insentif entities.

2) Entity $t b \_s e k o l a h$ is related 1 to many or one to many with entities $t b \_s a r a n a$, $t b \_p r a s a r a n a, t b \_s c h o o l \_p e s e r t a d i d i k \_a g a m a, t b \_s c h o o l \_p e s e r t a d i d i k \_m u t a s i$, tb_school_pesertadidik_usia tb_school_pesertadidik_kps and tb_school_pesertadidik_transportation.

\subsubsection{Implementation Results}

The results of the implementation of the development phase of the Mengwi SIUPT generated for each Administrator (UPT Employee), School Employee and Head of UPT are as follows.

\section{a) Login Page}

The login page at SIUPT Mengwi has been repaired based on recommendations from the evaluation phase. 1) There is a button to view the password to minimize errors when logging in. The login page display can be seen in Figure 4.

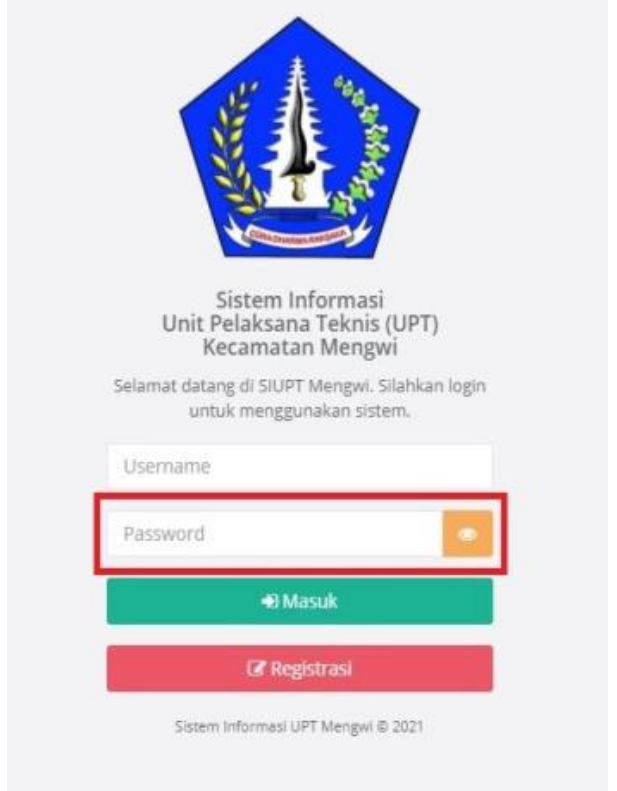

Figure 4. Login Page

\section{b) Administrator Main Page}

The main page displays news data, information data and menus on SIUPT Mengwi. On the administrator's main page, improvements have been made based on recommendations from the evaluation phase. 1) In the side menu, SIUPT Mengwi has been simplified or grouped according to their respective functions, 2) moved the exit button to the top right of the page, 3) the use of Indonesian in the whole system. The main page view can be seen in Figure 5. 


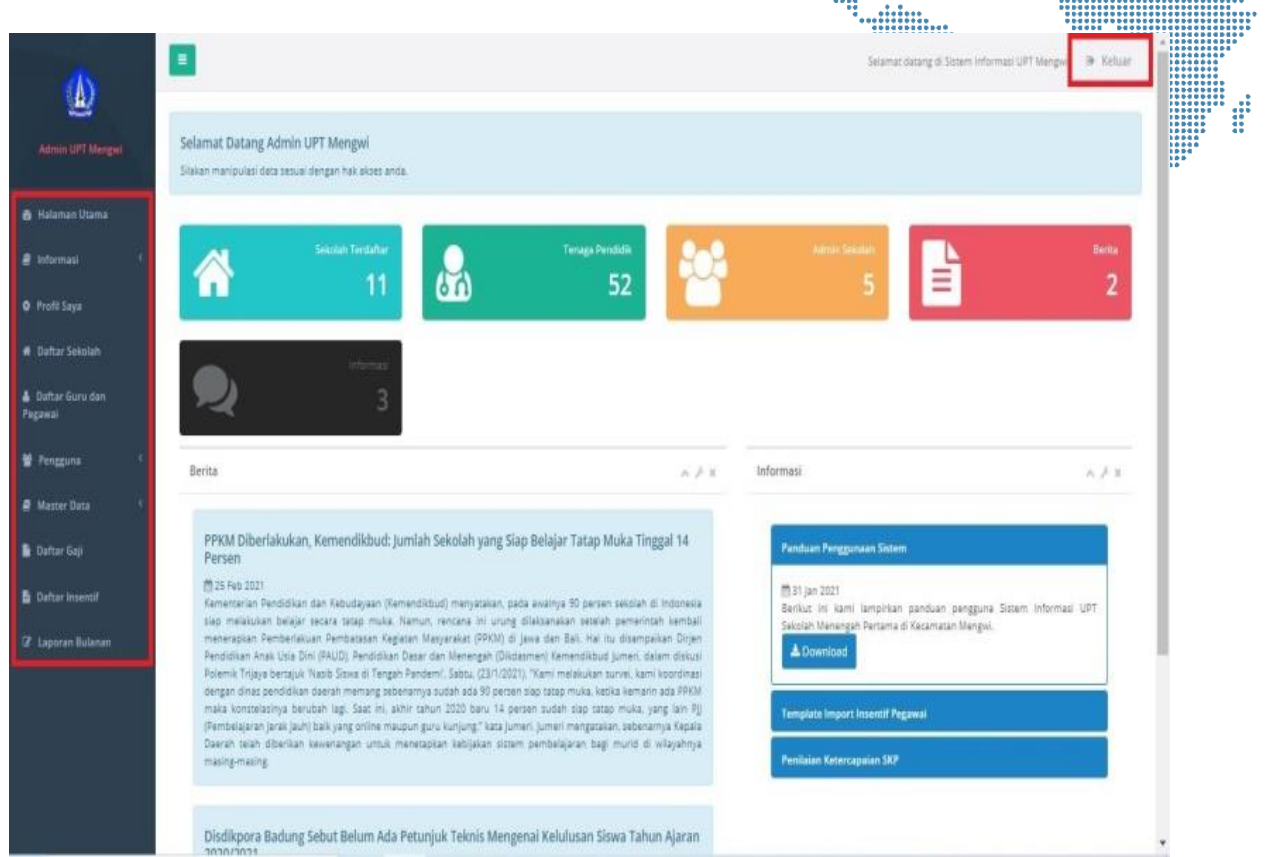

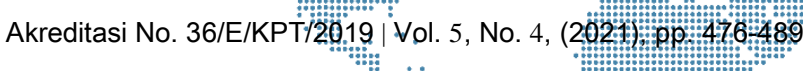

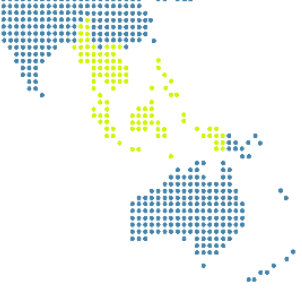

Figure 5. Administrator Main Page

\section{c) Teacher and Employee Data Page}

On the teacher and employee data page displays teacher and employee data. On the teacher and employee pages, improvements have been made based on recommendations from the evaluation phase. 1) There is a show school button to filter data to display data for each school, 2) on this page the view and change action button is already on the left side of the page, 3) download and upload data menus are at the top of the page, 4) move the search feature to the top of the page. The display of teacher and employee data pages can be seen in Figure 6.
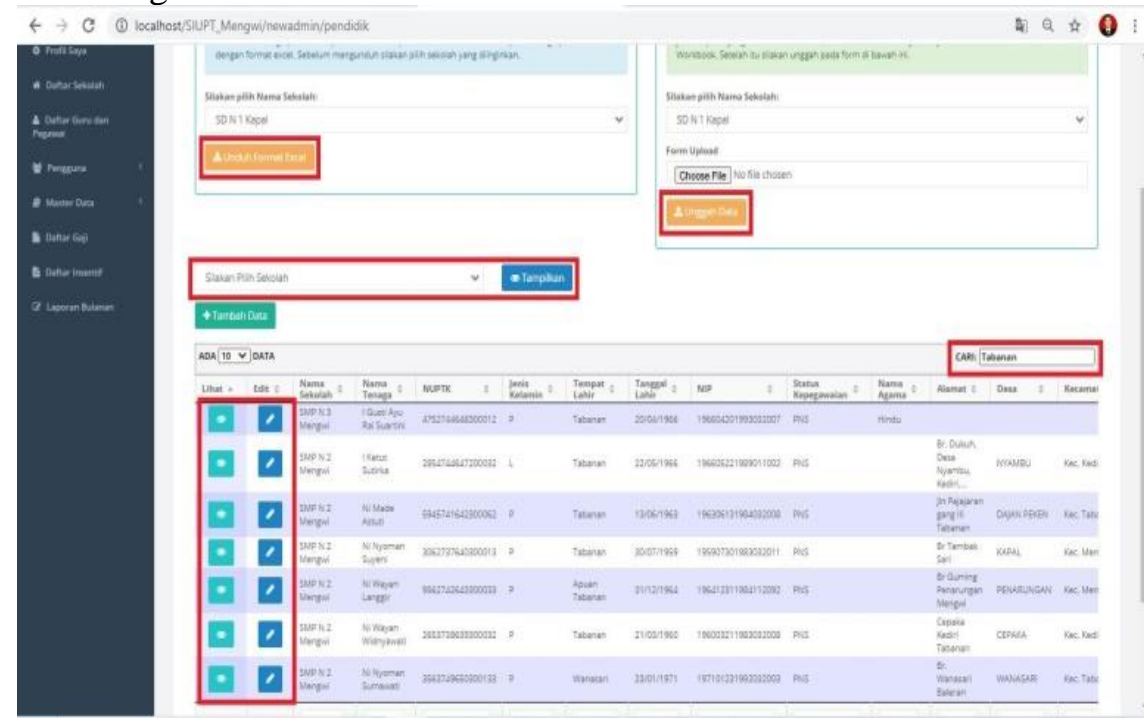

Figure 6. Teacher and Employee Pages

\section{d) School Data Page}

On the school data page, the button layout has been changed as follows. 1) For the add school data page the save data button is at the bottom of the page, 2) for the data change page the save button is at the top and bottom of the page. Changes to the layout of the save button have been made on all menus on the system, in accordance with the results of the recommendations in the evaluation phase. The display of the Add School Data page can be seen in Figure 7. 


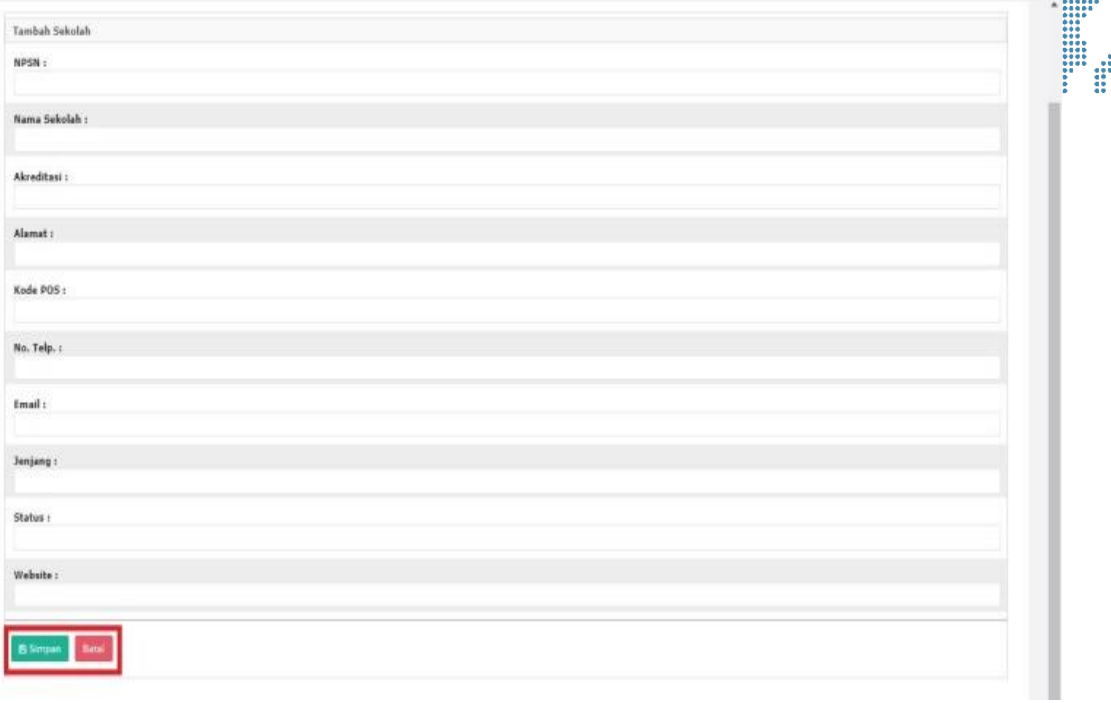

Figure 7. Add School Data Page

On the change school data page, changes are made to the location of the save button at the top and bottom of the page, its function is if the user changes the data at the top, the user does not take too long to find the save button which is also at the bottom of the page. The display of changing school data can be seen in Figure 8.
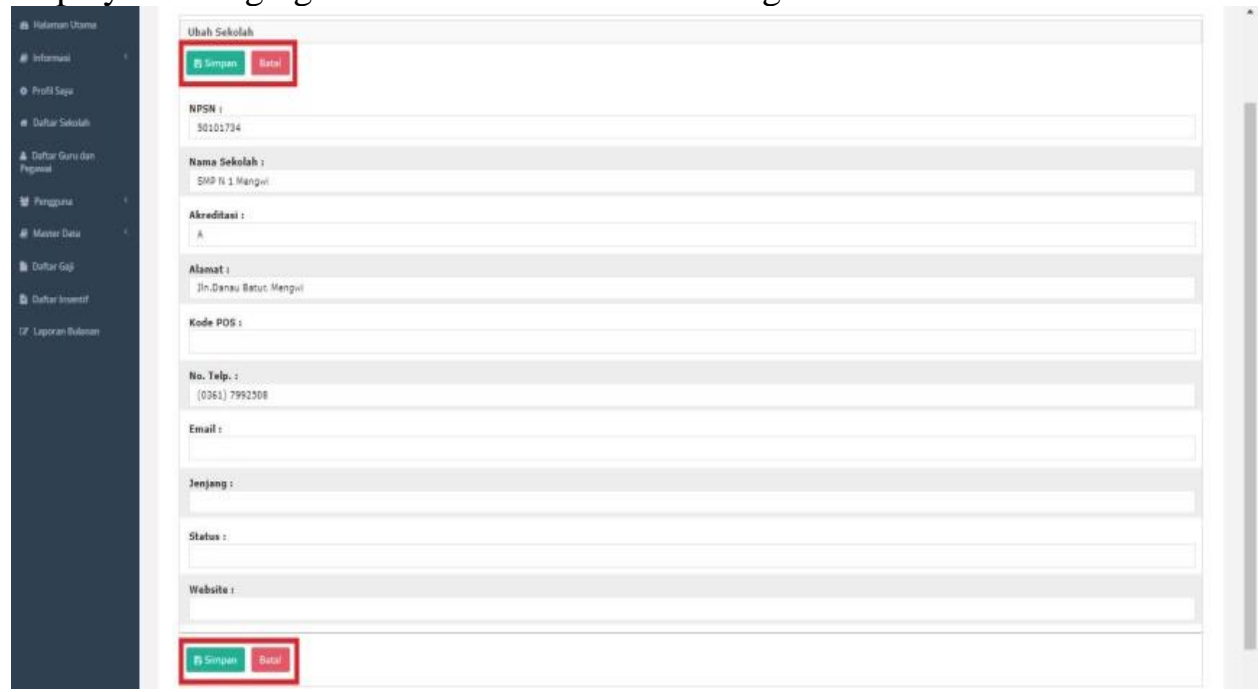

Figure 8. Change School Data Page

\section{e) Monthly Report Page}

On the monthly report page, improvements have been made based on recommendations from the evaluation phase. 1) Monthly and yearly report download menus are available according to user needs. The monthly report page can be seen in Figure 9. 
Figure 9. Monthly Report Page

\subsubsection{Evaluation Results - Performance Measurement}

From the results of the evaluation using the Performance Measurement technique, on the administrator page (UPT employees), elementary school employees, junior high schools and the UPT head using 20 respondents. The evaluation results are described as follows.

a) Administrator Page Effectiveness Results and Analysis.

It can be concluded that in experiment 1 and experiment 2 there were no failures, indicating that all 26 tasks on the administrator's page were successfully carried out by all respondents. Therefore, the administrator page at SIUPT Mengwi can be said to have been effective, because there were no problems or failures when using the system.

b) Results and Analysis of the Effectiveness of School Employee Pages.

It can be concluded that in experiment 1 and experiment 2 there were no failures, indicating that all 21 tasks on the School Employee page were successfully carried out by all respondents. Therefore, the School Employee page at SIUPT Mengwi can be said to have been effective, because there were no problems or failures when using the system.

c) Results and Analysis of the Effectiveness of the Head of UPT.

It can be concluded that in experiment 1 and experiment 2 there were no failures, indicating that all 14 tasks on the UPT Head page were successfully carried out by all respondents. Therefore, the UPT Head page on SIUPT Mengwi can be said to have been effective, because there were no problems or failures when using the system.

d) Administrator Page Efficiency Results and Analysis.

Efficiency data processing is done by comparing the value of Asymp.Sig which is worth 0.05 for each task. It can be seen that the Asymp.Sig value of each task on the Administrator page is greater than 0.05. It means that it can be concluded that statistically the 26 tasks carried out by respondents on the administrator page did not have a significant time difference between the time of trial 1 and trial 2 on the results of SIUPT development.

e) Results and Analysis of School Employee Page Efficiency.

Efficiency data processing is done by comparing the value of Asymp.Sig which is worth 0.05 for each task. It can be seen that the Asymp.Sig value for each assignment on the School Employee page is greater than 0.05. It means that it can be concluded that statistically the 21 tasks carried out by respondents on the School staff page were 


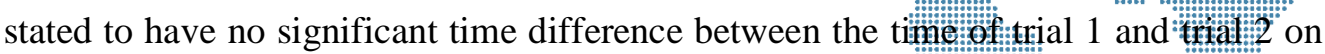
the results of SIUPT development.

f) Results and Efficiency Analysis Head of UPT.

Efficiency data processing is done by comparing the value of Asymp.Sig which is worth 0.05 for each task. It can be seen that the Asymp.Sig valilue of each task on the UPT Head page is greater than 0.05 . It means that it can be concluded that statistically the 14 tasks carried out by respondents on the Head of the UPT page did not have a significant time difference between the time of trial 1 and trial 2 on the results of SIUPT development.

\subsubsection{Evaluation Results - Retrospective Think Aloud}

Recapitulation of data on difficulties or problems as well as suggestions and criticisms from respondents when using SIUPT Mengwi on the admin page (UPT employees), school employees and UPT heads are explained as follows.

a) Administrator Page Recapitulation

The conclusion data from the data recapitulation of difficulties or problems when using SIUPT Mengwi as well as suggestions and criticisms obtained from respondents for using SIUPT Mengwi on the administrator page with RTA evaluation can be seen in Table 3.

Table 3. Development Phase - RTA Conclusion on Administrator Page

\begin{tabular}{|c|l|l|}
\hline No & Features/Aspects & \multicolumn{2}{|c|}{ Conclusion } \\
\hline 1. & Menu on system & $\begin{array}{l}\text { 1. Menus can be kept in position, even if the user } \\
\text { accesses the bottom of the page. }\end{array}$ \\
\hline 2. & $\begin{array}{l}\text { Notifications on the } \\
\text { system }\end{array}$ & $\begin{array}{l}\text { 1. Add success or failure messages when adding, } \\
\text { changing and saving data. }\end{array}$ \\
\hline
\end{tabular}

b) School Employee Page Recapitulation

The conclusion data from the recapitulation of data on difficulties or problems when using SIUPT Mengwi as well as suggestions and criticisms obtained from respondents for using SIUPT Mengwi for school employee page with RTA evaluation can be seen in Table 4.

Table 4. Development Phase - RTA Conclusion on School Employee Page

\begin{tabular}{|l|l|l|}
\hline No & Features/Aspects & \multicolumn{1}{c|}{ Conclusion } \\
\hline 1. & Menu on system & $\begin{array}{l}\text { Menus can be kept in position, even if the user accesses } \\
\text { the bottom of the page. }\end{array}$ \\
\hline 2. & $\begin{array}{l}\text { Notifications on } \\
\text { the system }\end{array}$ & $\begin{array}{l}\text { Add success or failure messages when adding, changing } \\
\text { and saving data. }\end{array}$ \\
\hline
\end{tabular}

c) Recapitulation of the Head of UPT

The conclusion data from the recapitulation of data on difficulties or problems when using SIUPT Mengwi as well as suggestions and criticisms obtained from respondents for using SIUPT Mengwi for the Head of UPT page with RTA evaluation can be seen in Table 5.

Table 5. Development Phase - Conclusion on Head of UPT Page

\begin{tabular}{|c|l|cl|}
\hline No & Features/Aspects & \multicolumn{2}{c|}{ Conclusion } \\
\hline 1. & Menu on system & 1. & $\begin{array}{l}\text { Menus can be kept in position, even if the user accesses } \\
\text { the bottom of the page. }\end{array}$ \\
\hline 2. & Button on system & 1. & A back button is added at the top of the page. \\
\hline
\end{tabular}



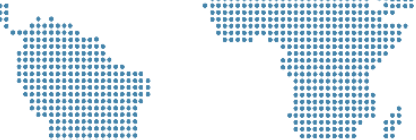

\subsubsection{Evaluation Results - User Experience Questionnaire}

The results of the user experience questionnaire showed that the tesults of the ni SIUPT development phase could give scores on the six aspects of the user experience with a very good category. The graphical results of the user experience questionnaire are shown in Figure 10.

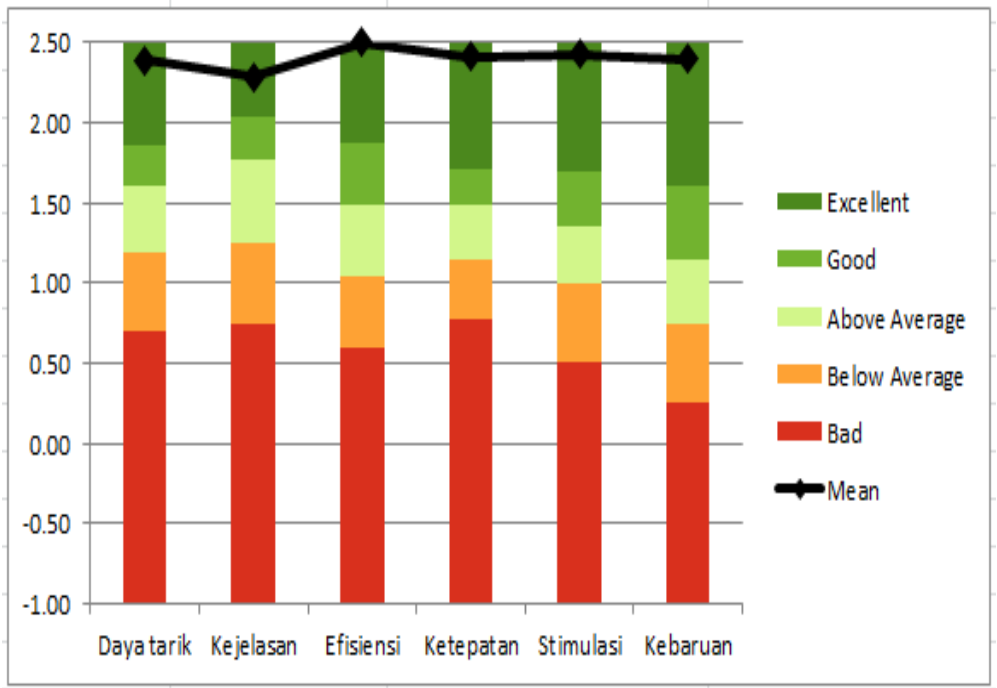

Figure 10. Development Phase - UEQ Graph Results

\section{Conclusion}

In the evaluation phase of the existing system, it was shown that from the analysis of the effectiveness of the Mengwi SIUPT user page it was still not effective because there were errors in the work carried out. In the statistical efficiency analysis, there was still a time difference between the first test and the second test on the task given. The value of user satisfaction showed that the attractiveness, efficiency and accuracy aspects got categories above the ideal average. The clarity aspect got a category below the ideal average. The conclusions obtained in the evaluation phase of the Mengwi SIUPT still need to be improved in several parts related to the attractiveness, efficiency, accuracy and clarity of the Mengwi SIUPT. Therefore, the evaluation and development of the Mengwi SIUPT continued to the incremental phase, namely the development and evaluation of the developed system.

The results of the recommendations for improvement are then used for data analysis in the development phase of SIUPT Mengwi by applying the incremental development model. After developing the incremental model, the re-evaluation stage is carried out with the aim of measuring the effectiveness and efficiency of the system, as well as measuring aspects of user satisfaction. The evaluation results after development show that SIUPT has been effective and efficient with no failures in the execution of tasks and there was no significant difference in the time of task execution between test 1 and test 2 . All aspects of user satisfaction are attractiveness aspects, clarity aspects, efficiency aspects, accuracy aspects, aspects of stimulation and aspects of novelty got a very good category. The final result of developing SIUPT Mengwi on interface and functional aspects could increase the user satisfaction.

For further research, it is necessary to make improvements to the menu position so that it remains in the initial position when the user accesses the bottom of the page. Notifications or error messages can also be added when the user makes changes as well as data storage and the need to add a back button for the entire menu on the system. 


\section{A sinta ${ }^{(0)}$}

References

[1] Amelia, A, "Evaluasi Antarmuka dan Pengalaman Pengguna website Serta coode Refactoring Pada Website E-Kosan," Jurnal Ilmiah Koniputier dan Infơmmatika (KOMPUTA), Vol. 5, No. 2, 2016.

[2] Dewi, I. K., Mursityo, Y. T., \& Mardi, R. R. P, “Analisis Usäbility Aplikasi Mobile Pemesanan Layanan Taksi Perdana Menggunakan Metode Webuse dan Heuristic Evaluation," Jurnal Pengembangan Teknologi Informasi Dan Ilmu Komputer, vol. 2, no. 8, pp.2909-2918, 2018.

[3] Indriyani, R., Dantes, G., dan Aryanto, K. Y. E, "Analisis Kebermanfaatan Website Sekolah Tinggi Pariwisata (STIPAR) Triatma Jaya Menggunakan Metode Usability Testing," International Journal of Natural Science and Engineering, Vol.1, No. 2, pp. 56-64, 2017.

[4] ISO 9241-11, "Ergonomic Requirements For Office Work With Visual Display Terminals (VDTs)", Part 11: Guidance on Usability, ISO, (1998).

[5] Handiwidjojo, Wimmie, and Lussy Ernawati, "Pengukuran Tingkat Ketergunaan (Usability) Sistem Informasi Keuangan Studi Kasus: Duta Wacana Internal Transaction (Duwit)," vol. 02, no. 1, pp. 49-55, 2016.

[6] Santoso, N. A., Virginia, G. dan Susanto, B, "Evaluation Interface Design to Build User Experience on SInTA Service Christian Duta Wacana University Yogyakarta," TRANSFORMATIKA, Vol.15, No.1, pp. 26 - 35, 2017.

[7] Schrepp, M. (2019). User Experience Questionnaire Handbook. www.ueqonline.org.

[8] Sommervile, I. (2014) Software Engineering - 10th Edition. Pearson Education Inc: Boston.

[9] Sularsa, A., Prihatmanto, A. S. dan Nugroho, E, "Evaluasi User Experiences Produk iDigital Museum dengan Menggunakan UEQ," Jurnal Teknologi Informasi, Vol. 2, No. 2, pp.56-62, 2015.

[10] Sugiyono. (2017). Statistika Untuk Penelitian (Cetakan Ke - 28). Bandung: Alfabeta.

[11] Yuliyana, T., Arthana, I. dan Agustini, K, "Usability Testing pada Aplikasi POTWIS," Jurnal Sains dan Teknologi, Vol. 8, No.1, pp. 12 - 22, 2019. 